Follistatin as potential therapeutic target in prostate cancer

Maria Vittoria Sepporta, Francesca Maria Tumminello, Carla Flandina, Marilena Crescimanno, Marco Giammanco, Maurizio La Guard al.

Targeted Oncology

ISSN 1776-2596

Targ Oncol

DOI 10.1007/s11523-013-0268-7



望 Springer 
Your article is protected by copyright and all rights are held exclusively by SpringerVerlag France. This e-offprint is for personal use only and shall not be self-archived in electronic repositories. If you wish to selfarchive your work, please use the accepted author's version for posting to your own website or your institution's repository. You may further deposit the accepted author's version on a funder's repository at a funder's request, provided it is not made publicly available until 12 months after publication. 


\title{
Follistatin as potential therapeutic target in prostate cancer
}

\author{
Maria Vittoria Sepporta • Francesca Maria Tumminello • \\ Carla Flandina • Marilena Crescimanno • \\ Marco Giammanco • Maurizio La Guardia • \\ Danila di Majo • Gaetano Leto
}

Received: 3 October 2012 / Accepted: 5 February 2013

(C) Springer-Verlag France 2013

\begin{abstract}
Follistatin is a single-chain glycosylated protein whose primary function consists in binding and neutralizing some members of the transforming growth factor- $\beta$ superfamily such as activin and bone morphogenic proteins. Emerging evidence indicates that this molecule may also play a role in the malignant progression of several human tumors including prostate cancer. In particular, recent findings suggest that, in this tumor, follistatin may also contribute to the formation of bone metastasis through multiple mechanisms, some of which are not related to its specific activin or bone morphogenic proteins' inhibitory activity. This review provides insight into the most recent advances in understanding the role of follistatin in the prostate cancer progression and discusses the clinical and therapeutic implications related to these findings.
\end{abstract}

Keywords Activin · Bone metastasis - Cancer · Follistatin . Prostate cancer

\section{Introduction}

Prostate cancer $(\mathrm{PCa})$ is the third most common cause of death from cancer in men of all ages and the most common cause of death from cancer in men over 75 years old [1,2]. The number of affected subjects is expected to increase as the population of males over the age of 50 grows worldwide [1, 2]. Complete surgical resection or radiotherapy is currently the only potentially curative treatment for patients with

M. V. Sepporta $\cdot$ F. M. Tumminello $\cdot$ C. Flandina

M. Crescimanno - M. Giammanco - M. La Guardia • D. di Majo •

G. Leto $(\varangle)$

Operative Unit of Physiology and Pharmacology,

University of Palermo, via Augusto Elia, 3,

90127 Palermo, Italy

e-mail: gaetano.leto@unipa.it localized prostate cancer. However, about one third of these patients relapse after radical prostatectomy due to undetected metastatic disease [3]. The lack of effective clinical treatments for prostate cancer reflects, in part, the incomplete knowledge of the molecular mechanisms involved in the development and progression of this tumor [4]. Therefore, a better understanding of this process may lead to the identification of new molecular targets and more effective therapeutic options in $\mathrm{PCa}$ treatment. In this scenario, emerging evidence indicates that activin (Act), a member of the transforming growth beta (TGF- $\beta$ ) superfamily of growth factors, appears to play a role in the malignant progression of prostate cancer [5-7]. This hypothesis is supported by growing experimental and clinical observations which highlight that the activin signaling pathway is deregulated in $\mathrm{PCa}$ and that this phenomenon is associated with the onset of more aggressive forms of this tumor [6,7]. The deregulation of the activin signaling pathway appears to be the result of several mechanisms including alterations in the expression level of some endogenous inhibitors of activin such as follistatin (FLS) $[6,7]$. Therefore, this inhibitor may be of potential clinical interest as a novel molecular target in the treatment of prostate cancer. The aims of the present paper are to provide an updated systematic review on the role of FLS in prostate cancer progression and to discuss the clinical and therapeutic implications of these novel findings.

\section{Follistatin: structure and functions}

Follistatin is a cystein-rich glycosylated polypeptide chain of 31-39 kDa that binds to Act with high affinity (850$500 \mathrm{pM})[8,9]$. This inhibitor was originally isolated from porcine ovarian follicular fluid and identified as a molecule implicated in the regulation of the secretion of folliclestimulating hormone $[8,9]$. FLS is a product of a single 
gene, located on the long arm chromosome 5 q11.2. Sequence analysis demonstrated that the $F L S$ gene consists of six exons separated by five introns transcribed into the precursor FLS317 and FLS344 messenger RNA (mRNA) forming at least two molecular weight forms by alternate splicing, i.e., FLS288 (from pre-FLS317) and FLS315 (from pre-FLS344) [10] (http://www.ncbi.nlm.nih.gov/LocusLink/ s). These isoforms contain a N-terminal domain and three domains, known as follistatin domains (FSD1, FDS2, and FDS3 respectively), which differ in their amino acid composition $[8,10]$. Each FLS domain consists of 73-77 amino acids and is distinguished by ten conserved cysteine residues. In particular, FSD1 contains an amino acid sequence known as a heparin binding sequence (HBS) that enables FLS to bind with high-affinity cell surface proteoglycans $[10,11]$. The heparin binding sequence of follistatin has been mapped to a lysine- and arginine-rich sequence within residues 75-86 in FSD1 [11]. Experimental in vivo studies show that FLS knockout mice dies soon after birth due to a variety of skeletal and cutaneous defects [12]. The transcription of FLS gene may be stimulated by Act, TGF- $\beta$, forkhead domain transcription factor L2 (FoxL2) via Smad proteins [13, 14], gonadotropin-releasing hormone [15], GLI2 (a transcription factor activated by hedgehog signaling) [16], dexamethasone [17], androgens [18], activators of Wnt signaling $[19,20]$ and 1,25-dihydroxyvitamin D $(1,25(\mathrm{OH}) 2 \mathrm{D} 3)$ [21]. Conversely, FLS gene expression has been shown to be downregulated, according to the cell type, by peroxisome proliferator-activated receptor gamma (PPRA- $\gamma$ ) or the transcriptor factor epiprofin, also known as Sp6 [22, 23]. The FLS288 and FLS315 splice variant isoforms are the most common ones. They are widely present and differentially expressed in human tissues [8-10, 24, 25]. The longer FLS315 variant is predominant, while the FLS288 isoform accounts for less than $5 \%$ of the encoded mRNA [26, 27]. A third intermediate form, namely FS303, is presumably derived by proteolytic processing of the Cterminal domain of the FS315 variant [10, 26, 28]. Both FLS315 and FLS288 bind to Act with high affinity [9, 26, 28-32]. However, while FLS288 binds heparan sulfate proteoglycans with high affinity and may function as local regulator of Act [33], the longer FLS315 isoform, which is the main circulating form of this molecule, does not bind to the cell surface proteoglycans as it contains a tail consisting in an acidic extension at the $\mathrm{C}$ terminus of the 27 amino acid residues that can mask the heparin binding sequence of follistatin when the molecule is in an unbound state [9, 26, 31-33]. After binding to Act, the tail region unmasks the heparin binding sequence and the Act-FS315 complex can then bind to the cell surface proteoglycans [26, 30,33]. This phenomenon may explain the reason why FLS315 is secreted faster than FLS288 and why FLS315 may enter the circulation in a larger fraction [24]. Within the circulation,
$70-90 \%$ of FLS315 exists in the bound form [34]. The interaction between a molecule of FLS and a molecule of Act results in an almost irreversible binding complex that prevents Act to interact with its specific receptors (Fig. 1). This phenomenon ultimately leads to the inhibition of the biological effects induced by Act on various cells and tissues [8, 9, 28, 29, 31] (Fig. 1). Moreover, the irreversible binding of FLS to Act facilitates its internalization and the subsequent degradation of this complex by the lysosomal enzymes [8, 9, 29] (Fig. 1). The Act-FLS binding complex is generally composed of one Act and two FLS molecules [29] (Fig. 1). However, the exact function of the bound form remains to be defined. On the other hand, the FS315 does not appear to function as serum carrier for Act as its binding to this growth factor appears to be irreversible [9,10, 26, 28, 29, 31]. FLS may also bind with lower affinity to other members including bone morphogenic proteins (BMPs), in particular, BMP-2, BMP-4, BMP-5, BMP-6, BMP-7, BMP-11 [34-37], myostatin [38] and TGFß3 [39]. Additionally, FLS may also interact with two molecules that are not related to the TGF- $\beta$ family, namely, the serum pan-protease inhibitor $\alpha 2$ macroglobulin [40] and the pro-angiogenic factor angiogenin [41]. However, the functional significance of the interactions between FLS and these molecules remains to be fully elucidated.

\section{Follistatin's role in the physiological growth and function of prostate gland}

FLS is widely distributed in adult tissues including the prostate where it is usually co-localized with activin subunits and/or activin receptors [5, 8, 9, 25, 34, 42-45]. Compelling evidence indicates that the FLS/Act system plays a role in the paracrine/autocrine control of the physiological growth and functions of several tissues including the prostate gland [7, 42, 46-59]. The hypothesis that the interplay between FLS and Act may contribute to regulate prostate tissue homeostasis is suggested by the findings that FLS and Act receptors are predominantly co-localized in the developing prostatic epithelium [45-47]. Furthermore, this molecule is expressed throughout the epithelium of developing prostate and maintained into the mature glands [48]. In particular, immunohistochemical studies highlight a staining of FLS mainly in the stroma cells, while Act is mainly detected on the epithelial cells [46, 47]. Interestingly, the prostate epithelium and stroma differentially produce FS288 and FS315 isoforms respectively, thus suggesting a correlation between a specific isoform of FLS expression and cell type [43]. On the other hand, in vitro studies by Wang et al. [42] show that fresh human primary tissues and primary culture of human epithelial prostate cells actively secrete both Act and FLS that exert opposite effects, i.e., 


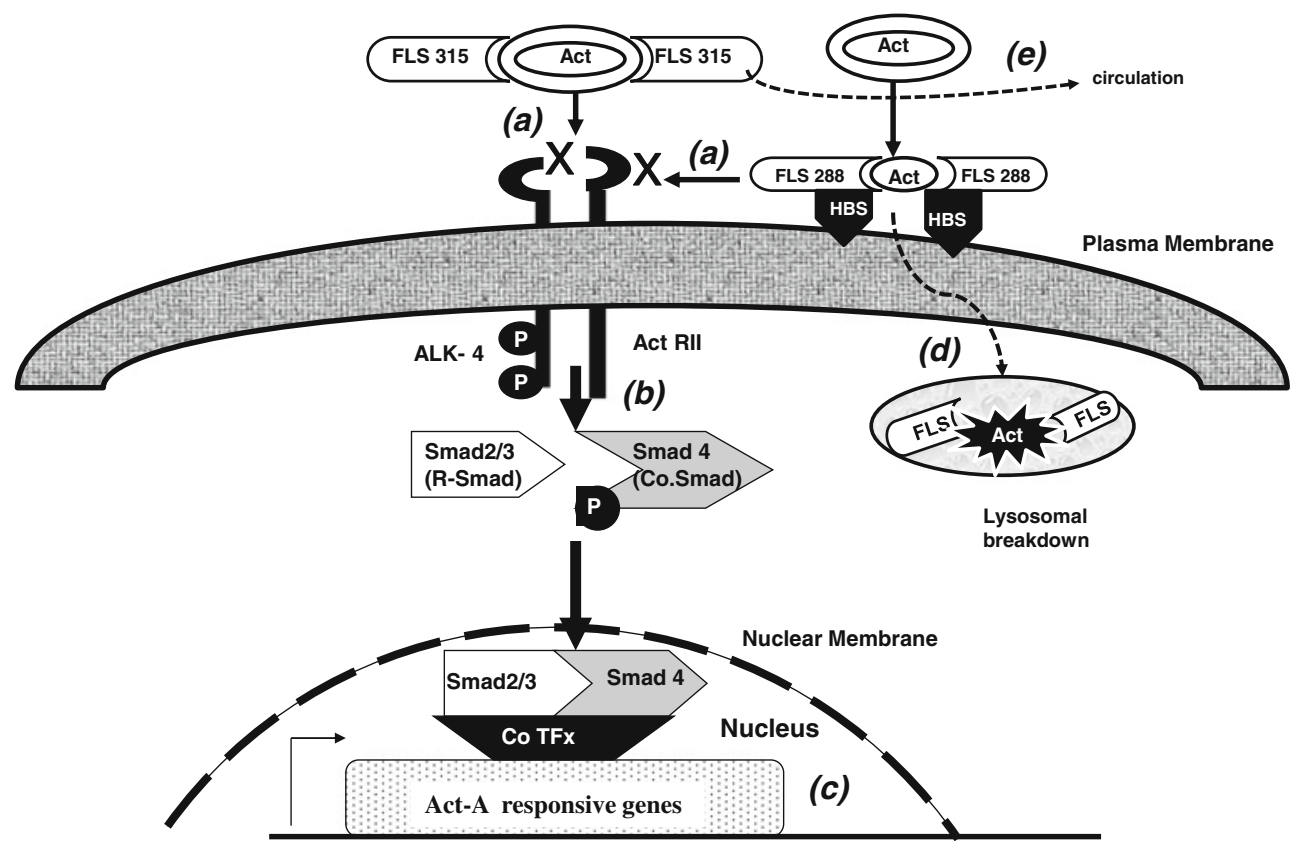

Fig. 1 Schematic representation of the activin-follistatin interactions and the resulting neutralization pathway. (a) FLS315 and FLS288 bind to Act with high affinity. The Act-FLS binding complex is composed of one Act and two FLS molecules. (a) Free Act dimers associate with membrane-bound FLS 288 which has a strong affinity for cell surface heparan sulfate proteoglycans (HSPG) (a). (b) The binding of FLS to Act blocks the interactions between Act and its receptors (Act type II receptor). (c) This phenomenon, ultimately inhibits the activation of activin mediated downstream signal transduction pathways and,

inhibiting or promoting effects respectively, on the growth of normal prostatic epithelial cells. These findings are consistent with the observations that FLS may act as a positive regulator of branching morphogenesis of the prostate while Act may function as a negative regulator of this phenomenon [43, 46-48]. The specific role of FLS in the promotion of the branching morphogenesis is further supported by the findings that in newborn prostate explants grown in the absence of testosterone, the addition of FLS increases the growth and branching of the prostate gland [47, 48]. These studies further stress the concept that a balanced interaction between FLS and Act is an essential prerequisite in order to regulate the prostate ductal growth and branching morphogenesis.

\section{Follistatin in prostate cancer progression}

The process of prostate organogenesis ultimately leads to the development of a mature gland composed of both highly differentiated contractile muscle cells and secretory epithelial cells $[7,47,48]$. Experimental evidence shows that, in physiological conditions, reciprocal homeostatic interactions between smooth muscle and epithelial cells contribute to regulate cell growth quiescence and functional differentiation [46-48]. However, perturbations of these cell-cell interactions consequently, the biological effects induced by this growth factor on various cells. $(\boldsymbol{d})$ The irreversible binding of FLS to Act facilitates its internalization and the subsequent degradation of this complex by the lysosomal enzymes. (e) FLS315, which is the main circulating form of this molecule, exhibits limited binding to HSPG. The fate of these complexes and the function of this pathway are unclear. However it is currently suggested that circulating FLS315 bound to Act to facilitate its clearance and/or prevent the diffusion of this cytokine from its local site of action

may cause loss of control of the epithelial cell and muscle cell growth and differentiation and, eventually, may trigger the process of malignant transformation [47-51]. As the FLS/Act system appears to have a role in the regulation of prostate growth and development, it is conceivable to hypothesize that a deregulation of this system may cause alterations of the normal homeostasis of prostate tissue and may contribute to the development and progression of prostate cancer [5-7, 46-48]. In support of this hypothesis, in vitro studies on human LNCaP androgen-sensitive prostate cancer cells highlight that FLS expression increases during the progression of prostate cancer toward more malignant androgen-independent disease variants [40, 52-54]. Furthermore, other in vitro observations show that unlike $\mathrm{LNCaP}$ cancer cells which are responsive to the growth inhibitory effect of Act, androgen-independent PC3 human prostate cancer cells which, conversely, are resistant to the growth-promoting effects of Act actively secrete FLS [7, $37,40,44]$. In particular, PC3 tumor cells predominantly express the FS288 isoform while LNCaP or DU145 tumor cells mainly express the FS315 variant [54, 55]. These findings are in line with some data from in vitro studies which highlight that FLS288 expression in PC3 tumor cells appears to be specifically associated with their resistance to the growthinhibiting effects of Act [22, 32, 40, 43]. Additional evidence in support of the specific involvement of FLS288 in this 
phenomenon is provided by the findings that the inhibitory activity of Act on LNCaP and DU145 cells can be counteracted by the addition of a tenfold excess of FLS288, but not by the addition of inhibin, another intracellular inhibitor of Act $[7,9,42,44,53]$. The preferential inhibiting effect of the FLS288 variant form on Act may be, in part, explained by the fact that this inhibitor is endowed with a neutralizing effect on Act greater than that of the FLS315 isoform and that FLS288, rather than FLS315, appears to be involved in the inactivation and clearance of activin [8, 26, 28, 29, 31] (Fig. 1). On the other hand, the growth-promoting effects of FLS on the prostate cancer cells are also indirectly proven by in vitro experiments which show that some plant-derived polyphenolic compounds with estrogen-like properties such as soy isoflavones may inhibit the prostate cancer cell growth by downregulating several genes involved in tumor cell proliferation, angiogenesis and metastasis, including FLS gene [56]. Furthermore, van der Poel et al. [57] also show that rapamycin, a specific inhibitor of the mammalian serine/threonine protein kinase mammalian target of rapamycin (mTOR), inhibits PC3 prostate cancer cells proliferation by causing cell cycle arrest in G1 phase and that this phenomenon is associated with an increase in the expression levels of BMP-4 and a decrease in the levels of FLS. Intriguingly, recent studies by Havard et al. [58] highlight that Act may promote in vitro the entry of $\mathrm{PCa}$ cells in a dormant state caused by a slight increase of the osmotic pressure in culture medium. On the basis of these findings, it should be conceivable to speculate that an increase in the expression level of FLS may facilitate the escape of tumor cells from a dormant state regulated by Act thus fostering the growth and dissemination of these cells. Finally, Ye et al. [59] show that the loss of endogenous BMP-7 in the prostate cancer cells is associated with an increased invasiveness and motility which appears to be facilitated by alterations in the expression level of some BMPs antagonists including FLS. Although these studies indicate that the mechanisms through which FLS may promote the malignant progression of $\mathrm{PCa}$ appears to be essentially correlated to its Act and or BMP inhibitory activity, accumulating evidence indicates that this molecule may also contribute to promote $\mathrm{PCa}$ progression by additional mechanisms not related to its Act or BMP inhibitory activity. For instance, recent observations by Gao et al. [60] show that FLS may be up-regulated and translocated to the nucleoli in the HeLa cells in response to glucose deprivation. The overexpression of FLS, in turn, negatively regulates rRNA synthesis and ribosome biogenesis. These effects are known to delay glucose deprivation-induced apoptosis [61]. Conversely, a downregulation of FLS elicits opposite effects [60]. As the increased resistance of cancer cells to glucose deficiency contributes positively to tumor progression [61], it is reasonable to hypothesize that FLS, through these mechanisms, could indirectly foster tumor development. On the other hand, these data further confirm the previous findings of the same authors [41] highlighting that in HeLa cells, FLS is present in the nucleus and may interact with angiogenin, a 14$\mathrm{kDa}$ protein endowed with pro-angiogenic functions, including endothelial cell activation, which may also promote migration, invasion, proliferation, and formation of tubular structure [62-64]. Finally, FLS has been reported to bind to type III TGF- $\beta$ [39]. As this isoform appears to play a major role in regulating the inhibition of PCa growth [65], it should be conceivable to speculate that FLS might probably also promote the malignant progression of $\mathrm{PCa}$ by interacting with type III TGF- $\beta$.

\section{Follistatin and tumor angiogenesis}

Growing experimental observations indicate that FLS may be also involved in the regulation of tumor angiogenesis thereby fostering the malignant progression of prostate cancer. In this context, early studies of Kozian et al. [66] showed that FLS may promote in vitro the proliferation of human umbilical vein endothelial cells, while, in vivo, this molecule is moderately angiogenic. These findings are consistent with some in vitro observations showing that FLS is upregulated in proliferating human microvascular endothelial cells (MVEC), but not in tubular MVEC [67]. Moreover, Gao et al. [41] have identified FLS as a binding partner of angiogenin which is a potent stimulator of angiogenesis and tumor cell proliferation [68]. Furthermore, other in vitro observations highlight that FLS, in concert with vascular endothelial growth factor (VEGF), appears to facilitate the formation of new blood vessels by stimulating the production of matrix metalloproteinase-2 (MMP-2), a proteolytic enzyme implicated in tumor angiogenesis and bone metastasis formation in prostate cancer [69-71]. On the other hand, the hypothesis of a possible involvement of FLS on tumor angiogenesis is further corroborated by in vivo studies of Krneta et al. [72] who have recently described that FLS may function as a potent angiogenesis stimulator also in severe combined immunodeficiency (SCID) mice transplanted with R30C human mammary tumor cells. These findings fit well with other recent observations which highlight that potent antiangiogenic molecules present in dietary sources, such as derived polyphenolic compounds with estrogen-like properties, may inhibit $\mathrm{PCa}$ cells growth by downregulating the expression of several genes involved in the malignant progression of this tumor, including $F L S[56,73]$. However, unlike these findings, Ogino et al. [73] reported that, in NK celldepleted SCID mice, the transfection of FLS gene resulted in the suppression of the experimental multiple organ metastases due to the inhibition of angiogenesis by small-cell lung cancer cells. The discrepancies in these results are, in part, currently explained through the use of different animal tumor models and the possible different role of the Act/FLS system at different stages of tumor progression and in the malignant progression of the different types of tumors [72, 74-79]. 
Follistatin and metastasis

The possible involvement of FLS in tumor angiogenesis supports the concept that this molecule may also facilitate the dissemination of tumor cells to distant organs via the angiogenic route. In line with this hypothesis, emerging evidence suggests that, at least in some tumors, FLS appears to facilitate the metastatic process [7, $72,80-85]$. On the other hand, a possible involvement of FLS in the pathogenesis of bone metastasis is not surprising as this molecule has been shown to actively cooperate with activin $\mathrm{A}$ in the regulation of normal bone homeostasis [86-89]. Consequently, it is conceivable that a deregulation of FLS expression may eventually result in pathological alterations of the normal bone remodeling processes such as it occurs in metastatic bone diseases. This hypothesis is sustained by some our previous clinical studies that show a significant correlation between circulating levels of FLS and $\mathrm{PCa}$ progression [84]. These findings are also consistent with the results from other immunohistochemical and molecular biology observations that highlight a positive correlation between altered expression level of FLS in prostate cancer and a more aggressive behavior of this tumor $[7,51,52,85,90]$. The possible mechanisms behind the promoting activity of FLS of PCa bone metastasis formation remain currently to be unraveled. Nonetheless, recent in vitro studies suggest that this molecule, in addition to its tumor angiogenesis promoting activity, may also indirectly facilitate bone metastasis by modulating the adhesion and invasion of tumor cells via BMP-2, BMP-4, and BMP-7, which appear to play a key role in the formation of osteoblastic lesions associated with prostate cancer metastases [59, 90-93]. Interestingly, Simon et al. [94] have recently reported that FLS may indirectly promote tumor cell detachment and migration by up-regulating the expression levels of the enzyme A -Disintegrin and Metalloproteinase-15 (ADAM-15), a disintegrin which cleaves integrin molecules and whose altered expression has been shown to support tumor growth, endothelial interaction, and metastasis of prostate cancer cells [66, 91, 95].
Intriguingly, this latter mechanism has been described so far only for human prostate cancer and neuroblastoma cells [94, 96]. These findings are promising for the discovery of more selective and effective therapeutic strategies in the treatment of prostate cancer.

\section{Follistatin as a marker of prostate cancer progression}

The observations that FLS expression levels are altered in tumor tissues [7, 45, 52, 55, 87] and/or in body fluids [83, $84,93,94]$ of patients with prostate cancer are suggestive of a possible clinical usefulness of this inhibitor as an additional marker in the clinical management of these patients. However, studies directed toward this aims are still scanty. Nonetheless, some of our recent clinical observations highlight that FLS serum levels are significantly increased in patients with prostate cancer as compared to those determined in patients with benign prostate hyperplasia or healthy subjects [85]. These findings further confirm previous observations of Sardana et al. [84]. In addition, our investigations show a close relationship between FLS serum concentrations and the presence of bone metastasis or increased PSA levels in these patients and that the ratio between the serum concentration of FLS and Act in PCa patients significantly differs from that measured in normal subjects [85]. These results further suggest a possible relationship between a deregulation of the Act/FLS system and prostate cancer growth and progression, and a close relationship between FLS serum concentrations and the presence of bone metastasis or increased PSA levels in these patients. However, these studies additionally show that, in our series of patients, the diagnostic performance of FLS, as assessed by receiver operating characteristic curve, is not significantly different from that observed for PSA or Activin $[85,97]$. Moreover, the combination of FLS with PSA and/or Act does not result in an improved diagnostic accuracy as compared to that determined for each single molecule $[84,85,97]$. Although these findings appear to rule out a diagnostic usefulness of FLS in PCa patients, they indicate that this molecule may be of potential clinical interest as additional circulating marker for the therapeutic management and follow-up of PCa patients [84, 85, 94, 96]. Further
Table 1 Possible mechanisms not related to the Act or BMP inhibitory activity by which FLS may facilitate prostate cancer cell proliferation invasion and metastasis

\begin{tabular}{lc}
\hline Mechanism & Reference \\
\hline Delay of glucose deprivation-induced apoptosis & {$[60]$} \\
Stimulation of endothelial cell proliferation & {$[66]$} \\
Nuclear translocation and interactions with angiogenin & {$[41]$} \\
Stimulation of matrix metalloproteinase-2 & {$[69]$} \\
Stimulation of sprouting angiogenesis and VEGF expression & {$[72]$} \\
Up-regulation of disintegrin ADAM-15 & {$[94]$} \\
Modulation of adhesion and invasion of tumor cells & {$[90]$} \\
\hline
\end{tabular}


studies with a wider number of subjects may better define the clinical role of FLS in prostate cancer.

\section{Conclusions}

There is an increasing evidence that follistatin, an inhibitor of the pleiotropic cytokine of the TGF $\beta$ superfamily Activin, may be implicated in the malignant progression of prostate cancer $[5,7,52,54-56,83,88]$. Moreover, experimental and clinical observations indicate that FLS may foster the dissemination of tumor cell into distant organs $[7,88]$. In particular, recent findings indicate that in $\mathrm{PCa}$ FLS may facilitate bone metastasis formation through multiple mechanisms, some of which are independent from its Act or BMPs' inhibitory activity [7, 60, 64, 68, 71, 93] (Table 1). The possible implication of FLS in facilitating bone metastasis formation in patients with prostate cancer is further suggested by some our recent clinical observations that highlight a positive correlation between altered expression levels of FLS and prostate cancer growth and/or presence of bone metastasis [83, 84]. Moreover, recent findings show that FLS may up-regulate ADAM-15, a disintegrin whose altered expression has been shown to specifically facilitate growth, endothelial interaction, and metastasis of prostate cancer cells and neroblastoma cells [66, 91, 94, 95]. These findings make FLS an attractive target for novel therapeutic options in the prevention and treatment of prostate cancer $[56,57,72]$ and a potentially useful biomarker in the clinical management of patients with this tumor $[83,84$, 92-94, 96]. In support of these hypotheses, recent in vitro experiments report that plant-derived polyphenolic compounds, namely, soy isoflavones, may inhibit prostate cancer cell growth and that this therapeutic effect is also correlated with a downregulation of the FLS gene [56]. Similarly, rapamycin, a specific inhibitor of the mammalian serine/threonine protein kinase mTOR, inhibits PC3 prostate cancer cells proliferation by causing cell cycle arrest in the G1 phase, a phenomenon which is associated with a decrease of FLS t levels in this case too [57]. These findings warrant further investigations in order to better assess the clinical role of FLS in prostate cancer.

Conflict of interest The authors declare no conflicts of interest.

\section{References}

1. Carson CC 3rd (2006) Carcinoma of the prostate: overview of the most common malignancy in men. N C Med J 67(2):122-127
2. Ferlay J, Autier P, Boniol M, Heanue M, Colombet M, Boyle P (2007) Estimates of the cancer incidence and mortality in Europe in 2006. Ann Oncol 18(3):581-592

3. Simmons MN, Stephenson AJ, Klein EA (2007) Natural history of biochemical recurrence after radical prostatectomy: risk assessment for secondary therapy. Eur Urol 51:1175-1184

4. Gioeli D (2005) Signal transduction in prostate cancer progression. Clin Sci 108:293-308

5. Risbridger GP, Schmitt JF, Robertson DM (2001) Activins and inhibins in endocrine and other tumors. Endocrine Rev 22(6):836858

6. Risbridger GP, Mellor SL, McPherson SJ, Schmitt JF (2001) The contribution of inhibins and activins to malignant prostate disease. Mol Cell Endocrinol 180(1-2):149-153

7. Gold E, Risbridger G (2012) Activins and activin antagonists in the prostate and prostate cancer. Mol Cell Endocrinol 359(1-2):107112

8. Phillips DJ, de Kretser DM (1998) Follistatin: a multifunctional regulatory protein. Front Neuroendocrinol 19(4):287-322

9. Welt C, Sidis Y, Keutmann H, Schneyer A (2002) Activins, inhibins, and follistatins: from endocrinology to signaling. A paradigm for the new millennium. Exp Biol Med 227:724-752

10. Sugino K, Kurosawa N, Nakamura T, Takio K, Shimasaki S, Ling N, Titani K, Sugino H (1993) Molecular heterogeneity of follistatin, an activin-binding protein. Higher affinity of the carboxyl-terminal truncated forms for heparan sulfate proteoglycans on the ovarian granulosa cell. J Biol Chem 68:15579-15587

11. Inouye S, Ling N, Shimasaki S (1992) Localization of the heparinbinding site of follistatin. Mol Cell Endocrinol 90:1-6

12. Matzuk MM, Lu N, Vogel H, Sellheyer K, Roop DR, Bradley A (1995) Multiple defects and perinatal death in mice deficient in follistatin. Nature 374(6520):360-363

13. Bartholin L, Maguer-Satta V, Hayette S, Martel S, Gadoux M, Corbo L, Magaud JP, Rimokh R (2002) Transcription activation of FLRG and follistatin by activin A, through Smad proteins, participates in a negative feedback loop to modulate activin A function. Oncogene 21(14):2227-2235

14. Blount AL, Schmidt K, Justice NJ, Vale WW, Fischer WH, Bilezikjian LM (2009) FoxL2 and Smad3 coordinately regulate follistatin gene transcription. J Biol Chem 284(12):7631-7645

15. Winters SJ, Ghooray D, Fujii Y, Moore JP Jr, Nevitt JR, Kakar SS (2007) Transcriptional regulation of follistatin expression by $\mathrm{GnRH}$ in mouse gonadotroph cell lines: evidence for a role for cAMP signaling. Mol Cell Endocrinol 271(1-2):45-54

16. Eichberger T, Kaser A, Pixner C, Schmid C, Klingler S, Winklmayr M, Hauser-Kronberger C, Aberger F, Frischauf AM (2008) GLI2-specific transcriptional activation of the bone morphogenetic protein/activin antagonist follistatin in human epidermal cells. Biol Chem 283(18):12426-12437

17. Hayashi K, Yamaguchi T, Yano S, Kanazawa I, Yamauchi M, Yamamoto M, Sugimoto T (2009) BMP/Wnt antagonists are upregulated by dexamethasone in osteoblasts and reversed by alendronate and PTH: potential therapeutic targets for glucocorticoid-induced osteoporosis. Biochem Biophys Res Commun 379(2):261-266

18. Singh R, Bhasin S, Braga M, Artaza JN, Pervin S, Taylor WE, Krishnan V, Sinha SK, Rajavashisth TB, Jasuja R (2009) Regulation of myogenic differentiation by androgens: cross talk between androgen receptor/beta-catenin and follistatin/transforming growth factorbeta signaling pathways. Endocrinology 150(3):1259-1268

19. Willert J, Epping M, Pollack JR, Brown PO, Nusse R (2002) A transcriptional response to Wnt protein in human embryonic carcinoma cells. BMC Dev Biol 2:2-8

20. Yao HH, Matzuk MM, Jorgez CJ, Menke DB, Page DC, Swain A, Capel B (2004) Follistatin operates downstream of Wnt4 in mammalian ovary organogenesis. Dev Dyn 230(2):210-215 
21. Necela BM, Su W, Thompson EA (2008) Peroxisome proliferatoractivated receptor gamma down-regulates follistatin in intestinal epithelial cells through SP1. Biol Chem 283(44):29784-29794

22. Garcia LA, King KK, Ferrini MG, Norris KC, Artaza JN (2011) 1,25(OH)2vitamin D3 stimulates myogenic differentiation by inhibiting cell proliferation and modulating the expression of promyogenic growth factors and myostatin in $\mathrm{C} 2 \mathrm{C} 12$ skeletal muscle cells. Endocrinology 152(8):2976-2986

23. Ruspita I, Miyoshi K, Muto T, Abe K, Horiguchi T, Noma T (2008) Sp6 downregulation of follistatin gene expression in ameloblasts. J Med Invest 55(1-2):87-98

24. Schneyer AL, Wang Q, Sidis Y, Sluss PM (2004) Differential distribution of follistatin isoforms: application of a new FS315-specific immunoassay. J Clin Endocrinol Metab 89(10):5067-5075

25. Thompson TB, Lerch TF, Cook RW, Woodruff TK, Jardetzky TS (2005) The structure of the follistatin: activin complex reveals antagonism of both type I and type II receptor binding. Dev Cell 9(4):535-543

26. Michel U, Albiston A, Findlay JK (1990) Rat follistatin: gonadal and extragonadal expression and evidence for alternative splicing. Biochem Biophys Res Commun 173(1):401-407

27. Schneyer AL, Hall HA, Lambert-Messerlian G, Wang QF, Sluss P, Crowley WF Jr (1996) Follistatin-activin complexes in human serum and follicular fluid differ immunologically and biochemically. Endocrinology 137(1):240-247

28. Hashimoto O, Kawasaki N, Tsuchida K, Shimasaki S, Hayakawa T, Sugino H (2000) Difference between follistatin isoforms in the inhibition of activin signalling: activin neutralizing activity of follistatin isoforms is dependent on their affinity for activin. Cell Signal 12(8):565-571

29. Sugino H, Sugino K, Hashimoto O, Shoji H, Nakamura T (1997) Follistatin and its role as an activin-binding protein. J Med Invest 44(1-2):1-14

30. Harrington AE, Morris-Triggs SA, Ruotolo BT, Robinson CV, Ohnuma S, Hyvönen M (2006) Structural basis for the inhibition of activin signalling by follistatin. EMBO J 25:1035-1045

31. Lerch TF, Shimasaki S, Woodruff TK, Jardetzky TS (2007) Structural and biophysical coupling of heparin and activin binding to follistatin isoform functions. J Biol Chem 282(21):15930-15939

32. Sidis Y, Mukherjee A, Keutmann H, Delbaere A, Sadatsuki M, Schneyer A (2006) Biological activity of follistatin isoforms and follistatin-like-3 is dependent on differential cell surface binding and specificity for activin, myostatin, and bone morphogenetic proteins. Endocrinology 147(7):3586-3597

33. Innis CA, Hyvönen M (2003) Crystal structures of the heparan sulfate-binding domain of follistatin. Insights into ligand binding. $\mathrm{J}$ Biol Chem 278(41):39969-39977

34. McConnell DS, Wang Q, Sluss PM, Bolf N, Khoury RH, Schneyer AL, Midgley AR Jr, Reame NE, Crowley WF Jr, Padmanabhan V (1998) A two-site chemiluminescent assay for activin-free follistatin reveals that most follistatin circulating in men and normal cycling women is in an activin-bound state. J Clin Endocrinol Metab 83(3):851-858

35. Iemura S, Yamamoto TS, Takagi C, Uchiyama H, Natsume T, Shimasaki S, Sugino H, Ueno N (1998) Direct binding of follistatin to a complex of bone-morphogenetic protein and its receptor inhibits ventral and epidermal cell fates in early Xenopus embryo. Proc Natl Acad Sci USA 95(16):9337-9342

36. Amthor H, Christ B, Rashid-Doubell F, Kemp CF, Lang E, Patel K (2002) Follistatin regulates bone morphogenetic protein-7 (BMP7) activity to stimulate embryonic muscle growth. Dev Biol 243(1):115-127

37. Glister C, Kemp CF, Knight PG (2004) Bone morphogenetic protein (BMP) ligands and receptors in bovine ovarian follicle cells: actions of BMP-4, -6 and -7 on granulosa cells and differential modulation of Smad-1 phosphorylation by follistatin. Reproduction 127(2):239-254
38. Amthor H, Nicholas G, McKinnell I, Kemp CF, Sharma M, Kambadur R, Patel K (2004) Follistatin complexes myostatin and antagonises myostatin-mediated inhibition of myogenesis. Dev Biol 270(1):19-30

39. Nogai H, Rosowski M, Grün J, Rietz A, Debus N, Schmidt G, Lauster C, Janitz M, Vortkamp A, Lauster R (2008) Follistatin antagonizes transforming growth factor-beta3-induced epithelialmesenchymal transition in vitro: implications for murine palatal development supported by microarray analysis. Differentiation 76(4):404-416

40. Phillips DJ, McFarlane JR, Hearn MT, de Kretser DM (1997) Inhibin, activin and follistatin bind preferentially to the transformed species of alpha 2-macroglobulin. J Endocrinol 155(1):65-71

41. Gao X, Hu H, Zhu J, Xu ZI (2007) Identification and characterization of follistatin as a novel angiogenin-binding protein. FEBS Lett 581(28):5505-5510

42. Wang Q, Tabatabaei S, Planz B et al (1999) Identification of an activin-follistatin growth modulatory system in the human prostate: secretion and biological activity in primary cultures of prostatic epithelial cells. J Urol 161(4):1378-1384

43. Anderson RA, Evans LW, Irvine DS, McIntyre MA, Groome NP, Riley SC (1998) Follistatin and activin A production by the male reproductive tract. Hum Reprod 13(12):3319-3322

44. Winnall WR, Wu H, Sarraj MA, Rogers PAW, de Kretser DM, Girling JE, Hedger M (2012) Expression patterns of activin, inhibin and follistatin variants in the adult male mouse reproductive tract suggest important roles in the epididymis and vas deferens. Reproduction, Fertility and Development doi: 10.1071/RD11287

45. Thomas TZ, Chapman SM, Hong W et al (1998) Inhibins, activins, and follistatins: expression of mRNAs and cellular localization in tissues from men with benign prostatic hyperplasia. Prostate 34(1):34-43

46. Cunha GR, Ricke W, Thomson A, Marker PC, Risbridger G, Hayward SW, Wang YZ, Donjacour AA, Kurita T (2004) Hormonal, cellular, and molecular regulation of normal and neoplastic prostatic development. J Steroid Biochem Mol Biol 92(4):221-236

47. Cancilla B, Jarred RA, Wang H, Mellor SL, Cunha GR, Risbridger GP (2001) Regulation of prostate branching morphogenesis by activin A and follistatin. Dev Biol 237(1):145-158

48. Prins GS, Putz O (2008) Molecular signaling pathways that regulate prostate gland development. Differentiation 76(6):641-659

49. Cunha GR, Hayward SW, Wang YZ (2002) Role of stroma in carcinogenesis of the prostate. Differentiation 60:473-485

50. Pritchard C, Mecham B, Dumpit R, Coleman I, Bhattacharjee M, Chen Q, Sikes RA, Nelson PS (2009) Conserved gene expression programs integrate mammalian prostate development and tumorigenesis. Cancer Res 69(5):1739-1747

51. Wong YC, Tam NN (2002) Dedifferentiation of stromal smooth muscle as a factor in prostate carcinogenesis. Differentiation 70:633-645

52. Vaarala MH, Porvari K, Kyllönen A, Vihko P (2000) Differentially expressed genes in two LNCaP prostate cancer cell lines reflecting changes during prostate cancer progression. Lab Invest 80(8):12591268

53. Härkönen P, Törn S, Kurkela R, Porvari K, Pulkka A, Lindfors A, Isomaa V, Vihko P (2003) Sex hormone metabolism in prostate cancer cells during transition to an androgen-independent state. $\mathrm{J}$ Clin Endocrinol Metab 88(2):705-712

54. van Schaik RH, Wierikx CD, Timmerman MA, Oomen MH, van Weerden WM, van der Kwast TH, van Steenbrugge GJ, de Jong FH (2000) Variations in activin receptor, inhibin/activin subunit and follistatin mRNAs in human prostate tumour tissues. Br J Cancer 82(1):112-117

55. McPherson SJ, Mellor SL, Wang H, Evans LW, Groome NP, Risbridger GP (1999) Expression of activin A and follistatin core 
proteins by human prostate tumor cell lines. Endocrinology 140:5303-5309

56. Handayani R, Rice L, Cui Y, Medrano TA, Samedi VG, Baker HV, Szabo NJ, Shiverick KT (2006) Soy isoflavones alter expression of genes associated with cancer progression, including interleukin-8, in androgen-independent PC-3 human prostate cancer cells. J Nutr 136(1):75-82

57. van der Poel HG, Hanrahan C, Zhong H, Simons JW (2003) Rapamycin induces Smad activity in prostate cancer cell lines. Urol Res 30(6):380-386

58. Havard M, Dautry F, Tchénio T (2011) A dormant state modulated by osmotic pressure controls clonogenicity of prostate cancer cells. J Biol Chem 286(51):44177-44186

59. Ye L, Lewis-Russell JM, Kynaston H, Jiang WG (2007) Endogenous bone morphogenetic protein-7 controls the motility of prostate cancer cells through regulation of bone morphogenetic protein antagonists. J Urol 178(3 Pt 1):1086-1091

60. Gao X, Wei S, Lai K, Sheng J, Su J, Zhu J, Dong H, Hu H, Xu Z (2010) Nucleolar follistatin promotes cancer cell survival under glucose-deprived conditions through inhibiting cellular rRNA synthesis. J Biol Chem 285(47):36857-368564

61. Lyssiotis CA, Vander-Heiden MG, Muñoz-Pinedo C, Emerling BM (2012) Emerging concepts: linking hypoxic signaling and cancer metabolism. Cell Death Dis 3:329. doi:10.1038/ cddis. 2012.75

62. Li S, Ibaragi S, Hu GF (2011) Angiogenin as a molecular target for the treatment of prostate cancer. Curr Cancer Ther Rev 7(2):83-90

63. Yoshioka N, Wang L, Kishimoto K et al (2006) A therapeutic target for prostate cancer based on angiogenin-stimulated angiogenesis and cancer cell proliferation. Proc Natl Acad Sci USA 103(39):14519-14524

64. Tsuji T, Sun Y, Kishimoto K et al (2005) Angiogenin is translocated to the nucleus of HeLa cells and is involved in ribosomal RNA transcription and cell proliferation. Cancer Res 65(4):1352-1360

65. Ajiboye S, Sissung TM, Sharifi N, Figg WD (2010) More than an accessory: implications of type III transforming growth factor-beta receptor loss in prostate cancer. BJU Int 105(7):913-916

66. Kozian DH, Ziche M, Augustin HG (1997) The activin-binding protein follistatin regulates autocrine endothelial cell activity and induces angiogenesis. Lab Invest 76(2):267-270

67. Glienke J, Schmitt AO, Pilarsky C, Hinzmann B, Weiss B, Rosenthal A, Thierauch KHD (2000) Differential gene expression by endothelial cells in distinct angiogenic states. Eur J Biochem 267(9):2820-2830

68. Gao X, Xu Z (2008) Mechanisms of action of angiogenin. Acta Biochim Biophys Sin (Shanghai) 40(7):619-624

69. Oh IS, Kim GH (2004) Vascular endothelial growth factor upregulates follistatin in human umbilical vein endothelial cells. Biotechnol Bioprocess Eng 9:201-206

70. Bauvois B (2012) New facets of matrix metalloproteinases MMP-2 and MMP-9 as cell surface transducers: outside-in signaling and relationship to tumor progression. Biochim Biophys Acta 1825(1):29-36

71. Littlepage LE, Sternlicht MD, Rougier N, Phillips J, Gallo E, Yu Y, Williams K, Brenot A, Gordon JI, Werb Z (2010) Matrix metalloproteinases contribute distinct roles in neuroendocrine prostate carcinogenesis, metastasis, and angiogenesis progression. Cancer Res 70:2224-2234

72. Krneta J, Kroll J, Alves F, Prahst C, Sananbenesi F, Dullin C, Kimmina S, Phillips DJ, Augustin HG (2008) Dissociation of angiogenesis and tumorigenesis in follistatin- and activinexpressing tumors. Cancer Res 66:5686-5695

73. Li WW, Li VW, Hutnik M, Chiou AS (2012) Tumor angiogenesis as a target for dietary cancer prevention. J Oncol. doi:10.1155/ $2012 / 879623$
74. Ogino H, Yano S, Kakiuchi S, Muguruma H, Ikuta K, Hanibuchi M, Uehara H, Tsuchida K, Sugino H, Sone S (2008) Follistatin suppresses the production of experimental multiple-organ metastasis by small cell lung cancer cells in natural killer cell-depleted SCID mice. Clin Cancer Res 14:660-667

75. Seder CW, Hartojo W, Lin L et al (2009) Upregulated INHBA expression may promote cell proliferation and is associated with poor survival in lung adenocarcinoma. Neoplasia 11(4):388-396

76. Chlenski A, Liu S, Baker LJ et al (2004) Neuroblastoma angiogenesis is inhibited with a folded synthetic molecule corresponding to the epidermal growth factor-like module of the follistatin domain of SPARC. Cancer Res 64(20):7420-7425

77. Sakamoto H, Kimura H, Sekijima M, Matsumoto K, Arao T, Chikugo T, Yamada Y, Kitano M, Ito A, Takeyama Y, Kudo M, Nishio K (2012) Plasma concentrations of angiogenesis-related molecules in patients with pancreatic cancer. Jpn J Clin Oncol 42(2):105-112

78. Miyahara K, Nouso K, Tomoda T, Kobayashi S, Hagihara H, Kuwaki K, Toshimori J, Onishi H, Ikeda F, Miyake Y, Nakamura S, Shiraha H, Takaki A, Yamamoto K (2011) Predicting the treatment effect of sorafenib using serum angiogenesis markers in patients with hepatocellular carcinoma. J Gastroenterol Hepatol 26(11):1604-1611

79. Hofland J, van Weerden WM, Steenbergen J, Dits NF, Jenster G, de Jong FH (2012) Activin A stimulates AKR1C3 expression and growth in human prostate cancer. Endocrinology 153(12):57265734

80. Rossmanith W, Chabicovsky M, Grasl-Kraupp B, Peter B, Schausberger E, Schulte-Hermann R (2002) Follistatin overexpression in rodent liver tumors: a possible mechanism to overcome activin growth control. Mol Carcinog 35(1):1-5

81. Stove C, Vanrobaeys F, Van Devreese B, Beeumen J, Mareel M, Bracke M (2004) Melanoma cells secrete follistatin, an antagonist of activin-mediated growth inhibition. Oncogene 23(31):5330 5339

82. Grusch M, Drucker C, Peter-Vörösmarty B, Erlach N, Lackner A, Losert A, Macheiner D, Schneider WJ, Hermann M, Groome NP, Parzefall W, Berger W, Grasl-Kraupp B, Schulte-Hermann R (2006) Deregulation of the activin/follistatin system in hepatocarcinogenesis. J Hepatol 45(5):673-680

83. Kang Y, Siegel PM, Shu W et al (2003) A multigenic program mediating breast cancer metastasis to bone. Cancer Cell 3:537-549

84. Sardana G, Jung K, Stephan C, Diamandis EP (2008) Proteomic analysis of conditioned media from the PC3, LNCaP, and 22Rv1 prostate cancer cell lines: discovery and validation of candidate prostate cancer biomarkers. J Proteome Res 7(8):3329-3338

85. Tumminello FM, Badalamenti G, Fulfaro F, Incorvaia L, Crescimanno M, Flandina C, Sepporta MV, Leto G (2010) Serum follistatin in patients with prostate cancer metastatic to the bone. Clin Exp Metastasis 27(8):549-555

86. Kawabata N, Kamiya N, Suzuki N, Matsumoto M, Takagi M (2007) Changes in extracellular activin A: follistatin ratio during differentiation of a mesenchymal progenitor cell line, ROB-C26 into osteoblasts and adipocytes. Life Sci 81(1):8-18

87. Eijken M, Swagemakers S, Koedam M, Steenbergen C, Derkx P, Uitterlinden AG, van der Spek PJ, Visser JA, de Jong FH, Pols HA, van Leeuwen JP (2007) The activin A-follistatin system: potent regulator of human extracellular matrix mineralization. FASEB J 21(11):2949-2960

88. Gajos-Michniewicz A, Piastowska AW, Russell JA, Ochedalski T (2010) Follistatin as a potent regulator of bone metabolism. Biomarkers 15(7):563-574

89. Gajos-Michniewicz A, Pawlowska E, Ochedalski T, PiastowskaCiesielska A (2012) The influence of follistatin on mechanical properties of bone tissue in growing mice with overexpression of follistatin. J Bone Miner Metab 30(4):426-433 
90. Chen Q, Watson JT, Marengo SR, Decker KS, Coleman I, Nelson PS, Sikes RA (2006) Gene expression in the LNCaP human prostate cancer progression model: progression associated expression in vitro corresponds to expression changes associated with prostate cancer progression in vivo. Cancer Lett 244(2):274-288

91. Chen M, Sinha M, Luxon BA, Bresnick AR, O'Connor KL (2009) Integrin alpha6beta4 controls the expression of genes associated with cell motility, invasion, and metastasis, including S100A4/ metastasin. J Biol Chem 284(3):1484-1494

92. Feeley BT, Gamradt SC, Hsu WK, Liu N, Krenek L, Robbins P, Huard J, Lieberman JR (2005) Influence of BMPs on the formation of osteoblastic lesions in metastatic prostate cancer. J Bone Miner Res 20(12):2189-2199

93. Buijs JT, Petersen M, van der Horst G, van der Pluijm G (2010) Bone morphogenetic proteins and its receptors; therapeutic targets in cancer progression and bone metastasis? Curr Pharm Des 16(11):1291-1300

94. Simon DP, Vadakkadath Meethal S, Wilson AC, Gallego MJ, Weinecke SL, Bruce E, Lyons PF, Haasl RJ, Bowen RL, Atwood CS (2009) Activin receptor signaling regulates prostatic epithelial cell adhesion and viability. Neoplasia 11(4):365-376

95. Najy AJ, Day KC, Day ML (2008) ADAM15 supports prostate cancer metastasis by modulating tumor cell-endothelial cell interaction. Cancer Res 68(4):1092-1099

96. Li D, Chiu H, Gupta V, Chan DW (2012) Validation of a multiplex immunoassay for serum angiogenic factors as biomarkers for aggressive prostate cancer. Clin Chim Acta 413(19-20):1506-1511

97. Leto G, Incorvaia L, Badalamenti G, Tumminello FM, Gebbia N, Flandina C, Crescimanno M, Rini G (2006) Activin A circulating levels in patients with bone metastasis from breast or prostate cancer. Clin Exp Metastasis 23(2):117-212 